DOI: https://doi.org/10.34069/AI/2021.46.10.20 How to Cite:

Luan, L. (2021). Loan words and Internet expressions in Chinese linguistics. Amazonia Investiga, 10(46), 201-208. https://doi.org/10.34069/AI/2021.46.10.20

\title{
Loan words and Internet expressions in Chinese linguistics
}

\section{Заимствованные выражения и интернет-язык в китайской лингвокультуре}

\section{汉语中的外来词和网络语言研究}

Received: October 18, 2021

\begin{abstract}
The article examines loan words and modern Internet language in Chinese, the method of their translation, the mechanism of their transformation into stable expressions of the normative language. With the development of globalization and information technology, some neologisms and new expressions appear in the Chinese language. The study of this problem allows us to show the dynamic nature of the language, to consider the interaction of language and the development of society. The goals and objectives of the study are to identify the semantic volume of some loan words in the Chinese language, to analyze the impact of translation on the linguistic picture of the world, to explore new expressions associated with information science. For the study, an associative experiment is carried out among Chinese respondents, language fragments from the media and the corpus of the modern Chinese language are analyzed. It is indicated that when entering into the Chinese linguistic composition, foreignlanguage words and the Internet language are often given a Chinese mentality and worldview. Different translation methods will have a certain impact on the cognition and world outlook of native Chinese speakers.
\end{abstract}

Keywords: Chinese language, linguistic picture of the world, Internet language, loan words, translation.
Accepted: November 11, 2021

Written by:

Luan Luan ${ }^{79}$

https://orcid.org/0000-0002-2173-2177

\begin{abstract}
Аннотация
В статье исследуются заимствованные слова и современный язык Интернета в китайском языке, способ их перевода, механизм их преобразования в устойчивые выражения нормативного языка. C развитием глобализации и информационных технологий в китайском языке появляются некоторые неологизмы и новые выражения. Изучение этой проблематики позволяет показать динамическую природу языка, рассмотреть взаимодействие языка и развития общества. Цели и задачи исследования - выявить семантический объем некоторых заимствованных слов в китайском языке, проанализировать влияние перевода на языковую картину мира, изучить новые выражения, связанные с информатикой. Для исследования проводится ассоциативный эксперимент среди китайских респондентов, анализируются языковые фрагменты из СМИ и корпуса современного китайского языка. Указывается, что входя в состав китайского языка, иноязычным словам и языку Интернета часто придается китайский менталитет и мировоззрение. Различные методы перевода окажут определенное влияние на познание и мировоззрение носителей китайского языка.
\end{abstract}

Ключевые слова: заимствованные слова, китайский язык, перевод, язык Интернета, языковая картина мира.

${ }^{79} \mathrm{PhD}$ student, RUDN University, Russia. 
本文研究了汉语中的外来词和现代网络语言, 分析了它们的翻译方法, 解析了它们转化为规范语 言的机制。随着全球化和信息技术的发展, 汉语中出现了一些外来词和网络新词。对这个问题的研 究使我们能够展示语言的动态变化, 考虑语言与社会发展的相互作用。该研究的目标在于确定汉 语中一些外来词的语义范围, 分析不同翻译方式对汉语母语者的语言世界图景的影响, 探索与信 息科学相关的新的表达方式。本研究在中国受访者中进行了联想实验, 分析了来自媒体的语段和 现代汉语语料库中的语言材料。研究表明，外来词和网络语言引入汉语时往往被赋予中华民族的 心态和价值观。不同的翻译方式会对汉语母语者的认知和世界观产生一定的影响。

关键词: 翻译, 汉语, 外来词, 网络语言, 语言世界图景.

\section{Introduction}

No language is an independent, closed system. With the blending of cultures, it will not only absorb loan words but also present new concepts and expressions as the society develops and changes. Generally speaking, the introduction of loan words between similar languages often uses phonetic transcription. However, due to the particularity of the Chinese system and characters, many words from foreign languages are often translated according to their meanings when they are introduced into Chinese. In addition, Chinese characters usually have independent semantics, and the characters used in the formation of words will give Chinese people some potential impressions. Therefore, when loan words are introduced into Chinese, they integrate the national language picture, inherent impressions and values. With the advent of the Internet age, social media and emerging technologies have brought many new lifestyles. New concepts and expressions have emerged, quickly spread, become popular, and turn into a language unit widely accepted by the public. At the same time, the author found that online buzzwords that conform to traditional national values are more likely to become mainstream expressions and are widely used by the masses and media. The acceptance of these non-native language elements reflects the characteristics of the application of Chinese on the one hand, and the value system of the Chinese nation on the other.

This paper expounds on the influence of loan words and Internet terms on people's thinking and expression methods through investigation, examples, statistics, and reveals the mechanism of the combination of non-native language elements and Chinese. This research has practical significance for clarifying the influence of social changes and cultural penetration on language.

\section{Theoretical Framework}

Loan words introduced to express foreign concepts or new words of the times produced by changes in social development are a common phenomenon in languages of all countries. However, "individual languages are characterized by varying degrees of immanent disposition to adopt foreign lexical elements" (Novotna, 1967a, p. 103). For example, English, French, German and some other languages have more toleration of foreign lexical elements, which can be borrowed simply by transcription. The study of loan words has attracted the attention of a large number of scholars and has conducted research on them from different perspectives, such as the phenomenon of loan words in different languages (Lubotsky \& Starostin, 2011; Li, 1945; Zhou, 2016; Laufer, 1916), the influence of loan words on the native language (Takako, 1999), and the different translation modes of loan words (Perfilieva \& $\mathrm{Hu}, 2018)$.

The translation process in Chinese is relatively more complicated when introducing loan words, because the language symbols of Chinese are characters, and it is difficult to directly transcribe between Chinese characters and the letters of other languages. Since independent Chinese characters usually have certain inherent meanings, ordinary transliteration often fails to meet the purpose of translating loan words or may easily lead to misunderstandings of word meanings. So, in addition to the way of transliteration, in some cases, "the language reproduces a certain foreign model or forms a 


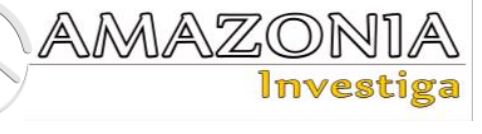

new lexical unit on its impulse by applying the usual native word-formation patterns" (Novotnab, 1967b, p. 613). In Chinese linguistics, it remains controversial which way of mastering loan words is preferable. Currently, a large number of words are borrowed in a mixed way. In the Chinese language, the following ways of mastering loan words are possible: graphic, phonetic, semantic, half-calc and abbreviation (Perfilieva \& Hu, 2018). Among them, the most common methods are phonetic and semantics translation. When loan words are introduced into Chinese, they sometimes cause changes in the semantic scope of the words, such as increased or decreased semantics. This situation mostly occurs in the words introduced through semantics translation, and relatively speaking, words introduced through transliteration retain the meaning contained in the etymology to a greater extent. The Chinese translation of loan words can influence the world language landscape of native Chinese speakers.

In addition to loan words, another type of nonnative language elements that appears a lot in modern Chinese is Internet buzzwords. "The impact of English upon Mandarin Chinese, coupled with the ever increasing use of Computer-Mediated Communication in Mainland China may have implications for change in Chinese" (Yang, 2007). Some Internet terms are gradually being accepted by standard Chinese and are widely used in mainstream media and daily communication among the general public. On the one hand, they affect the expression habits of modern Chinese people and the linguistic picture of the world. On the other hand, the traditional values and world outlook of the Chinese nation also affect the input of concepts and expressions from the Internet into Chinese.

With the vigorous development of the Internet age, some neologisms related to information technology have appeared in various languages. Some of these concepts are universal, while others are unique expressions generated under certain cultural backgrounds. The particular online lexical units in Chinese have received widespread attention, and linguists have studied their semantics, structure, translation forms. This article focuses on the translation of some foreign online words in Chinese, their semantic scope, and translation methods. In addition, under the influence of national values, the difference in the frequency of use of equivalent online words and the degree of their acceptance in Chinese are studied. There are relatively few studies in this area, which is also one of the innovations of this article.

\section{Methodology}

This article mainly uses morphological analysis to explain the translation mechanism of loan words and online vocabulary into Chinese, as well as their semantic scope. The article lists loan words and online expressions introduced into Chinese through two different methods: transliteration and free translation, and compares the semantic changes brought about by different translation methods. Through association experiments among 117 Chinese interviewees, the influence of Chinese characters used in the semantics translation of loan words on the understanding of lexical meanings by native Chinese speakers is explained and the unique picture of the Chinese language world is shown. In this article, statistics are made on the frequency of use of the two equivalent online concepts "likes" and "dislikes" in Chinese, and their acceptance by mainstream media to prove the influence of national values on the introduction of online culture.

\section{Results and Discussion}

Transliteration of loan words in Chinese is not uncommon. Loan words named in this way introduce the concept and the image directly into Chinese. In this case, the meaning of the word is more completely preserved, and usually, no new semantic elements are added. Here are a few examples of transliteration of loan words, their English forms are used as a reference (see Table 1). 
Table 1.

Transliteration of loan words in Chinese.

\begin{tabular}{lll}
\hline Original words in English & Transliteration in Chinese & $\begin{array}{l}\text { Phonetic transcription in } \\
\text { Chinese }\end{array}$ \\
\hline Coffee & 咖啡 & Kafei \\
Mocha & 摩卡 & Moka \\
Latte & 拿铁 & Natie \\
Cappuccino & 卡布奇诺 & Kabuqinuo \\
Sofa & 沙发 & Shafa \\
Macarons & 马卡龙 & Makalong \\
Bus & 巴士 & Bashi \\
\hline
\end{tabular}

(own source)

The inherent meanings of the individual Chinese characters in these transliterated words are weakened, and the meaning is expressed by the lexical unit as a whole. For example, the Chinese character 拿 is usually used as a verb with the meaning of "take", and the character 铁 has a meaning of "iron". But neither of these has a matter with the semantic volume of the word 拿

铁 (latte).

In contrast, loan words introduced through free translation often have semantic changes. The way of translation leads native Chinese speakers to produce unique cognitive psychology, which in turn shapes the national world outlook. Based on this conjecture, the author conducted an association experiment among 117 Chinese interviewees of different ages.

The concept of "pyramid" was introduced in China and is translated as "金字塔" (jin zi ta) - a tower, the shape of which is similar to the Chinese character 金 (jin) (Zhang, 2018). The definition of the word in the Chinese dictionary associates the figure of the pyramid with a Chinese character. It is shown that in the Chinese linguistic tradition, the borrowed culture is indirectly included in the linguistic picture of the world of the people, often merging with the native culture. Thus, new concepts in the Chinese language, to one degree or another, add some new semantic elements to the subject and in many situations determine the people's impression of the image. In a sense, it may seem obvious that words with special, culture-specific meanings reflect and convey a way of thinking (Vezhbitskaya, 2001).

In the questionnaire Chinese respondents were asked about the meaning of the lexeme "金" in the name of the pyramid. Out of 117 people, 38 chose the "color" of the pyramid, 46 chose "color and shape", 29 - "shape", only 4 - constituting the "linguistic sign" of the name, without meaning (see Diagram 1). It can be seen that the chosen hieroglyph that makes up the word affects people's perception of the object. It is interesting to note that although the official dictionary does not indicate the relationship between the lexeme 金 and the color of the pyramid, most Chinese people instinctively establish a connection between them since 金 denotes the color of gold in Chinese linguistic culture. Hieroglyphics laid the foundations for a special concrete-symbolic orientation of Chinese thinking, and developed figurative perception and imagination, which differs from abstract-conceptual thinking, which is the basis of alphabetic writing. In a hieroglyph the reader perceives not a concept, but a certain syncretic image (Vladimirova, 2018).

Diagram 1. The meaning of the hieroglyph "金" in the name of the pyramid. 


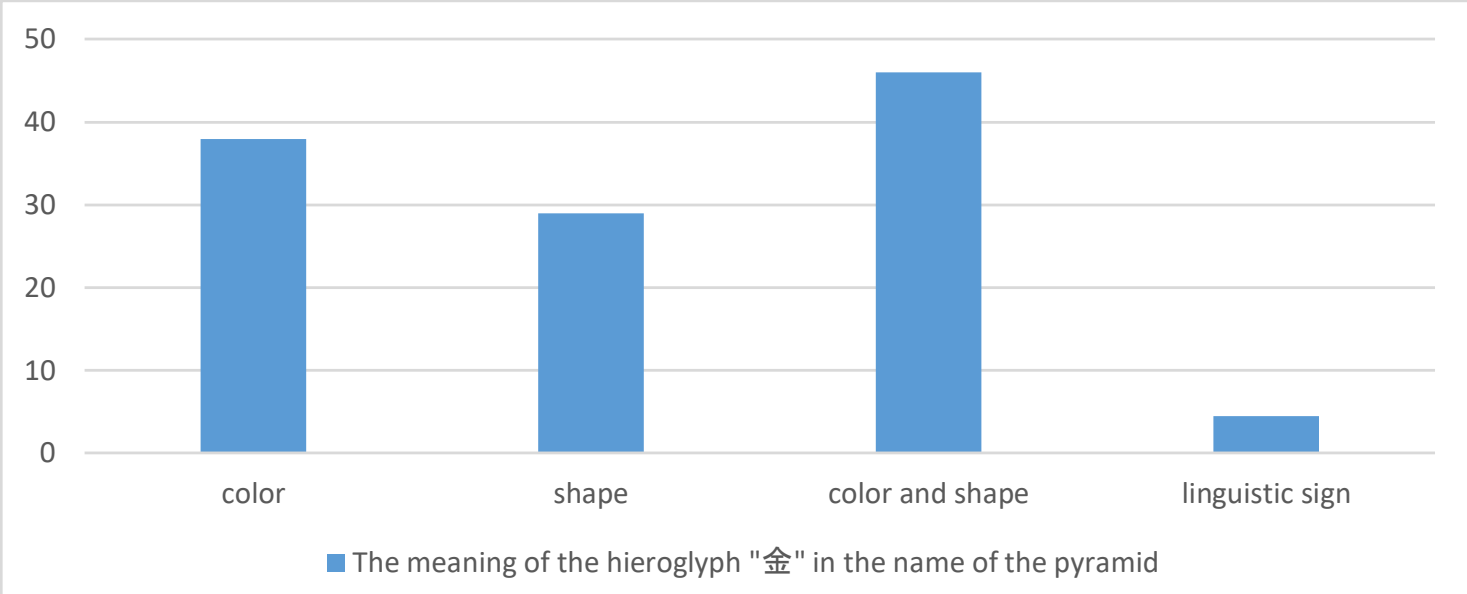

(own source)

Based on the survey results, it can be concluded that the loan word acquires a new semantic volume under the influence of the Chinese linguistic tradition, which is noticeably reflected in the cognitive activity of the people and their linguistic picture of the world.

This phenomenon is not isolated. The study of loan lexemes allows us to identify the impact of culture and speech tradition on the mental activity of the people. For example, penguins in Chinese are called "企我" (qi e), in which the character 企 (qi) means "盼望,企盼" (to desire fervently) (Zhang, 2018), and 鹅 (e) means goose.

Thus, 企鹅 is explained by a goose-like bird as expecting something when standing (Zhang, 2018). It can be assumed that the image of the penguin in the Chinese linguistic culture is enriched, and such an interpretation on the emotional level exists only in the Chinese language. In the English dictionary, for example, the explanation of the name penguin focuses on its image and lifestyle: a large, black and white sea bird that swims and cannot fly (Woodford, 2003). We conducted a survey among Chinese respondents, asking which group the penguin belongs to, birds, geese, or others. Of the 117 respondents, 29 people chose "geese", which confirms the influence of the lexeme 我 (goose) in the name of the penguin on the Chinese perception of this animal.

In some cases, free translation allows to embed more meanings in words, and in others - to narrow their semantic volume. For example, the loan word "sakura" in the Chinese linguistic tradition is understood as "樱花" (ying hua) - a kind of tree and its flower (Zhang, 2018). The hieroglyph "花" (hua) has the meaning of a flower, so in reality, the Chinese in most cases refer to sakura as a flower. This is evidenced by newspaper texts: "日本的樱花 3 月份开" (Sakura blooms in March) (Xun, Rao, Xiao \& Zang, 2016); " 樱花正含苞 " (Cherry is blossoming in the bud) (Xun et al., 2016). It can be assumed that the method of translation, to a certain extent, predetermines the semantic volume of the loan word and influences the linguistic picture of the world of the people. In this case, the name 樱花 restricts Chinese awareness of the term and its use. Chinese respondents were required to choose: sakura is a flower, a tree, or others. There are 101 votes for "flower", 56 votes for "tree", and some other votes for such options, like "fruit", "symbol of Japan", "Japanese festival". It is not difficult to conclude that the lexeme 花 (flower) to a certain extent limits the understanding of Chinese about sakura. Unlike the Chinese linguistic culture, in English, the loan word "sakura" is translated directly from the transcription of the Japanese word "sakura". Thus, we can say that the semantic volume of the term is exposed to the least influence of English culture, and accordingly - retains the greatest national character of the word. As proven, sakura has two parallel meanings in the Cambridge Dictionary: 1) a tree with a lot of very small flowers, especially the Japanese cherry tree; 2) the blossom (= flowers) of such trees.

The followings are some other freely translated loan words (see Table 2). Also, because the selected Chinese characters represent certain categories, they often mislead Chinese people, especially children. 
Table 2.

Translation of some loan words in Chinese.

\begin{tabular}{lll}
\hline English words & Chinese translations & $\begin{array}{l}\text { Hieroglyphs in names with meanings about the } \\
\text { category }\end{array}$ \\
\hline crocodile & 鳄鱼 & 鱼 - fish \\
kangaroo & 袋鼠 & 鼠 - mouse \\
hippopotamus & 河马 & 马-horse \\
\hline
\end{tabular}

own source

In addition to borrowed language units, online expressions also have a marked effect on Standard Chinese. The network has created a way of life and thinking for people and has a profound influence on the communication models of modern society (Leedham \& Cai, 2013). The Internet language, characterized by its expressiveness, novelty, and speed of distribution, enjoys wide popularity in modern times. Each significant component of an ethnos expresses its ethnic specificity in its way, it is far from the same in different concrete historical situations. This specificity is reflected primarily in the nominative units of the corresponding language (Mamontov, 2019). With the development of information technology, the names of popular applications and concepts in the virtual sphere, of course, become new linguistic units and appear in the Chinese language. Unlike the method of direct transcription in many languages, in Chinese linguoculture there are cases of mixing several translation methods when borrowing a new name. According to the data, most of the Chinese Internet language is the words written in hieroglyphs and among them, polysyllabic words are predominant (Glushkova \& Voronina, 2018). Here are some examples (see Table 3 ).

Table 3.

Chinese translation of the names of applications.

\begin{tabular}{|c|c|c|c|}
\hline $\begin{array}{l}\text { Names of } \\
\text { applications }\end{array}$ & $\begin{array}{l}\text { Chinese } \\
\text { translations }\end{array}$ & $\begin{array}{l}\text { Phonetic transcription in } \\
\text { Chinese }\end{array}$ & Meanings of characters \\
\hline Youtube & 油管 & Youguan & 油管 - oil pipe \\
\hline Airbnb & 爱彼迎 & Aibiying & $\begin{array}{l}\text { 爱 - love, 彼 - yours, 迎 - } \\
\text { welcome }\end{array}$ \\
\hline Uber & 优步 & Youbu & 优 - good, 步 - steps \\
\hline Booking & 缤客 & Binke & 缤 - colorful, 客 - guests \\
\hline
\end{tabular}

YouTube is translated as 油管 (oil pipe), since the front part of the word "You-" has the same spelling as the transcription of the character 油 (you) in Chinese and their pronunciations are similar, and the back part of "-Tube" as a separate word can be translated as 管 (pipe). So, the borrowed name is given a national flavor during the import process into the Chinese language. This phenomenon allows us to conclude that, even though certain universal concepts exist in each culture, their description, name, and semantic scope differ. This leads to a discrepancy between the linguistic picture of the world of different peoples.

The new concept from the network "赞" (like) has also been introduced into the Chinese language, and, accordingly, the syntactic construction "点赞" (the verb phrase) appears.

However, the opposite evaluative word "踩" (dislike) is used only in rare cases and is unpopular, especially since the construction of " 点踩" (the verb phrase) does not exist in Chinese at all. It should be emphasized that the "like" and "dislike" mentioned here are not used with their original meanings, but the meanings on social applications and other network platforms. Perhaps this has to do with the Chinese tradition of expressing kindness and appreciation to other people. In Chinese culture, tolerance and kindness towards others are considered one of the most valuable qualities of a person. This is reflected in Chinese linguistic culture, for example, 泛爱众 (overflow in love to all) 


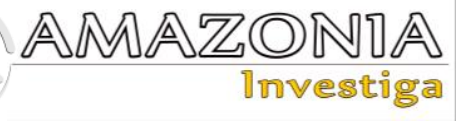

(Confucius, 480 BC-350 BC); 宽以待人 (being lenient towards others) (Luo, 1968) are qualities admired in Chinese culture.

It is worth mentioning that the expression 点赞 is also widely used in the media and some official cases, since linguistics is sensitive to changes in the discursive behavior of society (Slyshkin, 2000). According to statistics in the BCC Modern Chinese Language Corpus, the construction 点赞 was mentioned 2516 times in various newspapers, including the newspapers of the official print edition of the CPC Central Committee "People's Daily" within the state edition and a foreign edition, and this construction is often used in areas, which are not related to the network. Thus, it can be assumed that some expressions from the Internet can become a linguistic means of the official Chinese, and, accordingly, enrich the linguistic picture of the world of the people. It is also noticed that among a large number of new expressions and information from the Internet, the normative language primarily absorbs those linguistic units that correspond to national speech habits and moral values.

\section{Conclusions}

Many non-native language elements have undergone a localization process when they are introduced into Chinese, which is not only reflected in the translation of names, but also the convergence of values.

Analyzing the translation methods of how loan words and Internet terms are introduced into Chinese, it can be found that there are transliteration methods, semantics translation methods, and hybrid translation methods. Among them, the Chinese character morphemes in the transliterated loan words often do not express a meaning alone, but the lexical unit as a whole completes the naming function. In this case, the word can retain the original meaning to a large extent, and it rarely has an increase or a decrease of meaning. In contrast, loan words introduced in Chinese upon their meanings will encounter an increase or decrease in the meaning of the word in Chinese. Besides, the independent Chinese characters selected in the lexical unit will also contain a certain meaning, which will affect the cognitive activities of native Chinese speakers.

Many online vocabularies are introduced into Chinese by using a hybrid translation method, that is, on the premise of similar pronunciation, the selected Chinese character morphemes also express certain related meanings. This makes the terms commonly used in the world have more ethnic characteristics in the frame of the Chinese language.

In modern society, information is distributed and updated very quickly, which leads to the development and dynamics of the language system. Although the Internet has a comprehensive impact on the language system of the Chinese language, the officially adopted units must be consistent with the values of the national tradition.

The carried out associative experiment shows that the language system and speech traditions determine the way of understanding the world. Different expressions in the language, to a certain extent, lead to stereotyped associations of native speakers, which serves as the basis for linguocultural characteristics.

\section{Bibliographic references}

Confucius. (480 BC-350 BC). The Analects. Recovered from https://ctext.org

Glushkova, S. Yu. \& Voronina, M. K. (2018). Trends In The Development Of Chinese Internet Language. Modern Journal of Language Teaching Methods, 8 (9), 37-43.

Laufer, B. (1916). Loan-Words in Tibetan. T'oung Pao, 17 (4/5), 403-552.

Leedham, M. \& Cai, G. (2013). Besides ... on the other hand: Using a corpus approach to explore the influence of teaching materials on Chinese students' use of linking adverbials. Journal of Second Language Writing, 22 (4), 374-389. https://doi.org/10.1016/j.jslw.2013.07.002

Li, F. (1945). Some Old Chinese Loan Words in The Tai Languages. Harvard Journal of Asiatic Studies, 8 (3/4), 333-342. https://doi.org/10.2307/2717820

Lubotsky, A. \& Starostin, S. (2011). Turkic and Chinese loan words in Tocharian in Brigitte L. M. Bauer \& Georges-Jean Pinault (Ed.), Language in Time and Space (257-270). New York: De Gruyter Mouton. https://doi.org/10.1515/9783110897722.257

Luo, G. (1968). Romance of Three Kingdoms. Librebook. Recovered from https://librebook.me/romance_of_the_three_ kingdoms/voll/1

Mamontov, A. S. (2019). Cultural linguistics in the aspect of teaching the Russian language as a means of intercultural communication. Russian Language Studies, 
17 (2), 143-156. DOI: 10.22363/2618-81632019-17-2-143-156

Novotna, Z. (1967a). Linguistic Factors of the Low Adaptability of Loan-Words to the Lexical System of Modern Chinese. Monumenta Serica, 26(1), 103118. DOI: $10.1080 / 02549948.1967 .1174496$ 0

Novotna, Z. (1967b). Contributions to the Study of Loan-Words and Hybrid Words in Modern Chinese. Archiv Orientalni, 35, 613-648.

Perfilieva, N.V. \& Hu, P. (2018). Assimilation of English Loanwords in Chinese. RUDN Journal of Language Studies, Semiotics and Semantics, 9 (2), 287-301. DOI: 10.22363/2313-2299-2018-9-2-287-301

Slyshkin, G. G. (2000). From text to symbol: linguocultural concepts of precedent texts in consciousness and discourse. Moscow: Academia.

Takako T. (1999). The impact of loan-words on modern Japanese. Japan Forum, 11 (2), 231253. DOI: $10.1080 / 09555809908721634$

Vezhbitskaya, A. (2001). Understanding cultures through keywords. Moscow: Languages of Slavic culture. https://avidreaders.ru/read-book/ponimaniekultur-cherez-posredstvo-klyuchevyhslov.html

Vladimirova, $\mathrm{T}$. E. (2018). Russian discourse in intercultural communic ation: an existential-ontological approach. Ed. 3rd revised and add. Moscow: LENAND.

Woodford, K. (2003). Cambridge Advanced Learner's Dictionary. Cambridge: Cambridge University Press. URL: https://dictionary.cambridge.org/

Xun, E., Rao, G., Xiao, X. \& Zang, J. (2016). Research and Development of the BCC Corpus in the Background of Big Data. BBC. Recovered from http://bcc.blcu.edu.cn/zh/cid/2

Yang, C. (2007). Chinese Internet language: A sociolinguistic analysis of adaptations of the Chinese writing system. Language@Internet, 4(2).

Zhang, X. (2018). Chinese Dictionary. Recovered from http://www.hydcd.com/

Zhou, L. (2016). Loan Words in Modern English and Their Features. Sino-US English Teaching, 13 (3), 209-212. DOI: 10.17265/1539-8072/2016.03.006 